\title{
Preventive effect of dexketoprofen on postoperative pain
}

\author{
Postoperatif ağrıda deksketoprofenin preventif etkisi
}

\author{
İsmail Kerem GELIR, ${ }^{1}$ Sacit GÜLEÇ, ${ }^{2}$ Dilek CEYHAN²
}

\begin{abstract}
Summary
Objectives: Preventive analgesia has been defined as reduction in noxious stimuli during preoperative, intraoperative, and postoperative periods. The aim of the present study was to prevent central sensitization by administering ketamine infusion throughout the surgical procedure. In addition, possible preventive effects of dexketoprofen when administered before and after incision were evaluated.

Methods: Fifty patients were included. Group I was administered $50 \mathrm{mg}$ intravenous dexketoprofen prior to surgical incision, and Group II received the same amount 10 minutes after the incision had been made. Following induction of general anesthesia, all patients received a bolus of $0.50 \mathrm{mg} / \mathrm{kg}$ ketamine in $0.07 \mathrm{mg} / \mathrm{kg} / \mathrm{h}$ intravenous infusion.

Results: When postoperative visual analog scale values were compared, values for Group I after 1 and 4 hours were significantly lower than those of Group II. In addition, morphine consumption at 4, 8, 12, and 24 hours was significantly lower in Group I. Conclusion: Combined with the prevention of central sensitization with ketamine, administration of dexketoprofen prior to incision led to a lower rate of morphine consumption and more effective analgesia than post-incision administration.

Keywords: Ketamine; dexketoprofen; preventive analgesia; postoperative analgesia.
\end{abstract}

\section{Özet}

Amaç: Preventif analjezi ağrılı stimulusların preoperatif, intraoperatif ve postoperatif dönemde azaltılması olarak tanımlanır. Bu çalışmanın amacı tüm ameliyat boyunca uygulanan ketamin ile santral sensitizasyonu engelleyerek insizyon öncesi ve sonrası uygulanan deksketoprofen trometamolün preventif etkisini değerlendirmektir.

Gereç ve Yöntem: Bu çalışma 50 hasta üzerinde yapıldı. Grup l e cerrahi insizyondan önce $50 \mathrm{mg}$ deksketoprofen trometamol, Grup Il e cerrahi insizyondan 10 dakika sonra aynı miktarda deksketoprofen trometamol verildi. Genel anestezi indüksiyonunu takiben tüm hastalara $0.50 \mathrm{mg} \mathrm{kg-1} \mathrm{ketamine} \mathrm{bolus} \mathrm{yapıldı} \mathrm{ve} \mathrm{sonrasında} 0,07 \mathrm{mg} \mathrm{kg-1} \mathrm{h-1} \mathrm{infüzyon} \mathrm{şeklinde} \mathrm{ketamin} \mathrm{verildi.}$ Bulgular: Her iki gruptaki Vizuel Analog Skala değerleri karşılaştıııldığında, Grup I de 1. ve 4. deki Vizuel Analog Skala değerleri Grup II ye göre anlamlı ölçüde düşüktü. Ek olarak morfin tüketimi 4,8,12 ve 24.saatlerde Grup I de Grup II ye göre anlamlı düşüktü.

Sonuç: Santral sensitizasyonu önlemek için ketamin ile birlikte insizyon öncesi uygulanan deksketoprofen insizyon sonrası uygulama ile karşılaştırıldığında daha düşük morfin tüketimi ve daha efektif analjezi sağlar.

Anahtar sözcükler: Ketamin; deksketoprofen; preventive analjezi; postoperatif analjezi.

\section{Introduction}

Inducing analgesia before making a surgical incision is novel and promising method controlling pain during the preoperative period. Preventive analgesia have defined it as reduce the noxious stimuli includ- ing preoperative, intraoperative and postoperative period. Preventive analgesia incorporating multimodal antinociceptive treatment, started preoperatively and given for an increased duration including the postoperatively period. ${ }^{[1]}$

\section{'Department of Anesthesiology and Reanimation, Hacettepe Faculty of Medicine, Ankara, Turkey \\ 2Department of Anesthesiology and Reanimation, Osmangazi University Faculty of Medicine, Eskişehir, Turkey}

Submitted: 06.02.2015 Accepted after revision: 17.09.2015

Correspondence: Dr. Dilek Ceyhan. Eskişehir Osmangazi Üniversitesi Tıp Fakültesi, Anesteziyoloji ve Reanimasyon Ana Bilim Dalı 26100, Eskisehir, Turkey Tel: +90 - 222 - 2399052 e-mail: drdcetinkaya@mynet.com

(c) 2016 Turkish Society of Algology 
Controversies over the appropriate route of administration and the appropriate agent to use in preemptive analgesia stil contiunes unabated. For effective preventive analgesia, proper doses of suitable drugs should be administered at suitable times at the appropriate manner and both peripheric and central sensitization should be prevented.

Ketamine is an N-methyl $\mathrm{D}$-aspartate receptor (a glutamate receptor subtype) antagonist (NMDA) ${ }^{[2]}$ In previous studies, it has been established that NMDA receptor antagonist prevent central hypersensitization without modifying the routine response of the posterior horn to painful stimuli and that this drugs can be employed in preventive analgesia. ${ }^{[3]}$

Dexketoprofen is an active $\mathrm{S}$ enantiomer of racsemic ketoprofen and a nonselective nonsteroidal antiinflammatory drugs (NSAIDs). Dexketoprofen acts directly on the lesion region at the peripheral level and on the central nervous system at the central level. ${ }^{[4]}$

Many studies conducted to date have prevented, either central sensitization or peripheral sensitization alone. In these studies, the fact that surgical stimulation continued during the surgical procedure was disregarded and agents and administration routes that would produce an effect that would last throughout the procedure were not chosen. We believe that the most important cause of the contradictory results of the studies to date is that there are inefficiencies in the study designs. True preventive analgesia is made possible only by maintaining the effect of agents acting both on central and peripheral sensitization from before the operation until all surgical procedures are complete. Consequently the aim of the present study was to prevent central sensitization by performing ketamine infusion throughout the surgical procedure and to evaluate whether dexketoprofen has a preventive effect when administered before and after the incision.

\section{Material and Methods}

The present study was conducted 50 with patients 18-60 years old in ASA groups I-II who underwent elective abdominal hysterectomy after approval was obtained from the ethic committee. Patients who had renal, hepatic, pulmonary, cardiovascular system problems, increased intracranial pressure, a history of epilepsy, alcohol and opioid dependence, who were on chronic analgesics and had a history of allergies were excluded from the study.

The study was rondomized, double blind study and the patients were randomized into two groups using the closed envelope method. Group I (n 25) received an intravenous (iv) infusion of $50 \mathrm{mg}$ dexketoprofen in $100 \mathrm{ml}$ saline solution 30 minutes before the operation. Group II ( $\mathrm{n} 25$ ) received $100 \mathrm{ml}$ of iv saline solution 30 minutes before the operation. The patients were taken to the operating room and underwent routine monitoring. Following an infusion with $2 \mathrm{mg} / \mathrm{kg}$ of propofol and $0.6 \mathrm{mg} / \mathrm{kg}$ of rocuronium bromide, a bolus dose of $0.5 \mathrm{mg} / \mathrm{kg}$ of ketamine was administered with $0.07 \mathrm{mg} / \mathrm{kg} / \mathrm{h}$ using an iv infusion. The anesthesia was maintained was a mixture of 2-4\% sevoflurane and 50\% N2O-50\% O2. The patients in Group I received $100 \mathrm{ml}$ of iv saline solution 15 minutes after the incision was made, and the patients in Group II received $50 \mathrm{mg}$ of dexketoprofen in $100 \mathrm{ml}$ of saline solution 15 minutes after the incision. The ketamine infusion terminated after the skin was closed. No analgesic agent was used intraoperatively. Both groups received $3 \mathrm{mg}$ of iv morphine immediately before extubation.

All drugs were prepared by the investigators before the operations. The study drugs were added to 100 $\mathrm{ml}$ saline solution, and the numbers and administration hours were written on these prepared solutions. The drugs were administered by an anesthetist who was blinded to the patient grouping. Post-operative evaluations were performed by the same blinded doctor. On the day before surgery, all the patients were made familiar with the use of $100 \mathrm{~cm}$ a visual analog scale (VAS) identifying 0 as no pain and 100 the worst pain.

ECG values, systolic, diastolic and mean blood pressure and heart rate were recorded before and after induction, at 1,5,30 and 60 minutes after intubation and after extubation. In both groups, the patients were taken to the postoperative care unit and when the recovery score was 9 , a morphine infusion was started as the controlled analgesia method. (bolus dose of $2 \mathrm{mg}$ at 4 hours; maximum dose of $10 \mathrm{mg}$ ). The duration of anesthesia and the duration of the surgical procedure, as well as the amount of ketamine consumption, were 
Table 1. Patients characteristics and surgical data

\begin{tabular}{lccc}
\hline & Group I (n=25) & Group II (n=25) & P \\
\hline Age (years) & $48 \pm 6$ & $46 \pm 7$ & 0.561 \\
BMI, kg m ${ }^{2}$ & $30.4 \pm 4$ & $30.1 \pm 5$ & 0.709 \\
Duration of anesthesia (min) & $108 \pm 10$ & $109 \pm 10$ & 0.56 \\
Duration of surgery (min) & $91 \pm 8$ & $91 \pm 10$ & 0.59 \\
Total peroperative ketamine use (mg) & $37 \pm 2$ & $35 \pm 3$ & 0.56 \\
\hline
\end{tabular}

Data are mean \pm SD for continous variables; $p>0.05$

recorded. The time when the Aldrete recovery score was 9 , was considered to be 0 minutes. After $1,4,8,12$ and 24 hours, systolic, diastolic and midsystolic blood pressure, heart rate, VAS, morphine consumption and side effects (nausea, vomiting, increase in oral secretions, nightmares, diplopia, hallucinations, agitation) were recorded. If the VAS score was 40 or over during the follow-up period, an additional $2 \mathrm{mg}$ of i.v. morphine was administered. To treat nausea and vomiting, $10 \mathrm{mg}$ of iv metoclopramide was used.

\section{Statistical analysis}

To evaluate the findings obtained in this study, SPSS (Inc., Chicago, IL. USA) for Windows 17.0 was used to perform the statistical analyses. Descriptive statistics (i.e., means and standard deviations) were calculated to analyze the data. The Mann-Whitney $U$ test was used to compare quantitative parameters between groups. For intragroup comparisons of parameters, the Wilcoxon sign test was used. The results were calculated with $95 \%$ confidence intervals and evaluated at significance levels of $p<0.05$ and $p<0.01$.

\section{Results}

No significant difference was found between the groups in terms of demographic data, the duration of anesthesia, the duration of the surgical procedure or ketamine consumption ( $p>0.05$ ) (Table 1). In addition, there were no significant differences in terms of heart rate or arterial blood pressure values. There was no significant difference between the groups with regard to the time when the Aldrete recovery score reached 9 or the time when they first needed an analgesic (Table 2). When the postoperative VAS values were compared between the groups, the 1 and 4 hour VAS values were significantly lower in Group 1 than in Group $2(p<0.05)(p<0.01)$ (Figure 1). At 4 hours, 8 hours, 12 hours and 24 hours, morphine consumption was significantly lower in Group I compared with Group II $(p<0.01)$ (Figure 2). The distribution of postoperative side effects; Nausea affected 8 patients in Group I and 10 patients in Group II. In addition, vomiting occurred in 2 patients in Group I and 3 patients in Group II. These patients were treated with metoclopramide.

\section{Discussion}

This study revealed that in Group I, VAS values at 1 and 4 hours and morphine consumption at 4, 8, 16 and 24 hours were lower than the corresponding values in Group II. In addition, the study established that ketamine and dexketoprofen have no serious side effects.

Inflammatory substances released after the tissue is damaged with a skin incision sensitizes peripheral nociceptors. Central sensitization arises because of the increased sensitization of the neurons in the medulla spinalis. ${ }^{[5]} \mathrm{A}$ high number of NMDA receptors were revealed in the spinal cord. The stimulation mechanisms are quite complex, and stimulation becomes

Table 2. Recovery and first needed an analgesic time

\begin{tabular}{lccc}
\hline & Group I (n=25) & Group II (n=25) & P \\
\hline First needed and analgesic time (min) & $35.6 \pm 6$ & $34.2 \pm 6$ & 0.56 \\
Recovery time (min) & $25 \pm 3$ & $24 \pm 4$ & 0.66 \\
\hline
\end{tabular}

Data are mean $\pm S D$ 


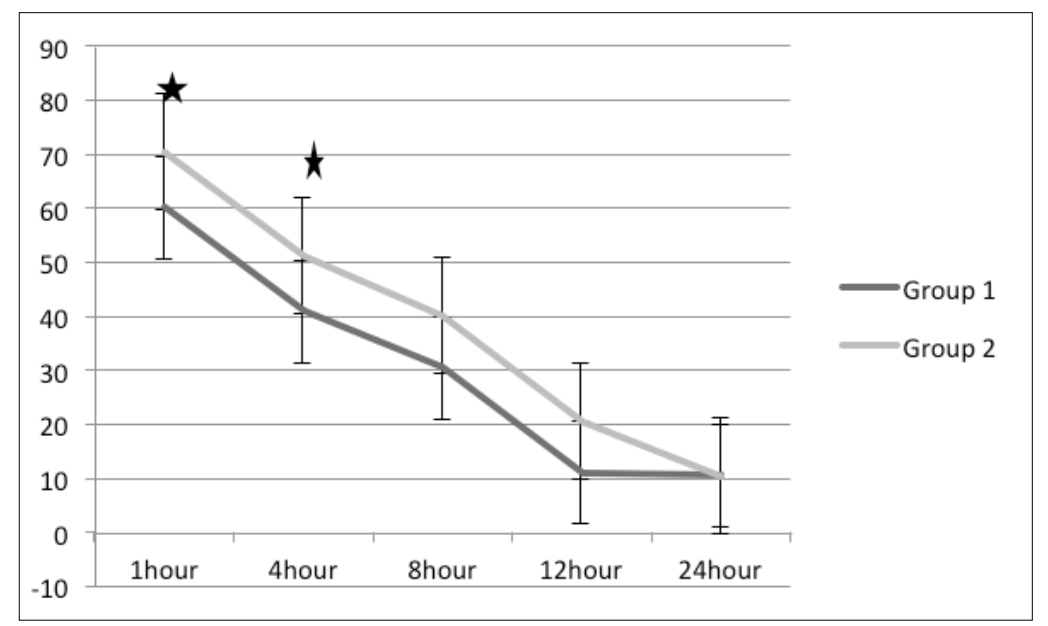

Figure 1.Visual analogue scale scores at $1 \mathrm{~h}, 4 \mathrm{~h}, 8 \mathrm{~h}, 12 \mathrm{~h}$ and $24 \mathrm{~h}$ of the groups.* $p<0,05$

possible only with repeated activation of $\mathrm{C}$ fibers. If the stimulation of the $C$ fibers continues long enough at a high enough frequency and intensity, NMDA receptors and ion channels are activated. This activation process is one of the most important causes of central hyperalgesia. ${ }^{[6]}$ Different drugs has been reported to prevent the development of long-term postsurgical pain, including gabapentin, ketamine, amitriptyline. ${ }^{[7]}$ Dullenkopf et al investigated whether single iv boluses of ketamine in two different doses had an effect on morphine consumption after moderate surgery. They concluded that there was no decrease in morphine consumption ${ }^{[8]}$ In another study, authors examinated the effect of 3 different doses of ketamine, given during anesthesia induction for cesarean delivery. They reported that no benefit was observed when ketamine used as an analgesic drug in doses of $0.25,0.5$ and $1 \mathrm{mg} / \mathrm{kg}^{\left[{ }^{[9]}\right.}$
The results of these studies indicate that ketamine has no preventive action. In the methodology of these studies ketamine was administered as a single dose, and no additional doses were administered during the procedure to prevent central sensitization. Patients were given NSAIDs (novaminsulfore8, lornoxicam9) both the study, but these drugs were given at the end of surgery. More the be honest, these drugs administered after starting peripheral sensitization. Under these conditions, it is not appropriate to interpret the results as evidence of the absence of a preventive effect.

The present study was based on these evaluations, and we aimed to prevent central sensitization with ketamin. Dexketoprofen, which was the real investigational drug in the study, was administered before and after the incision, with a placebo control, at an

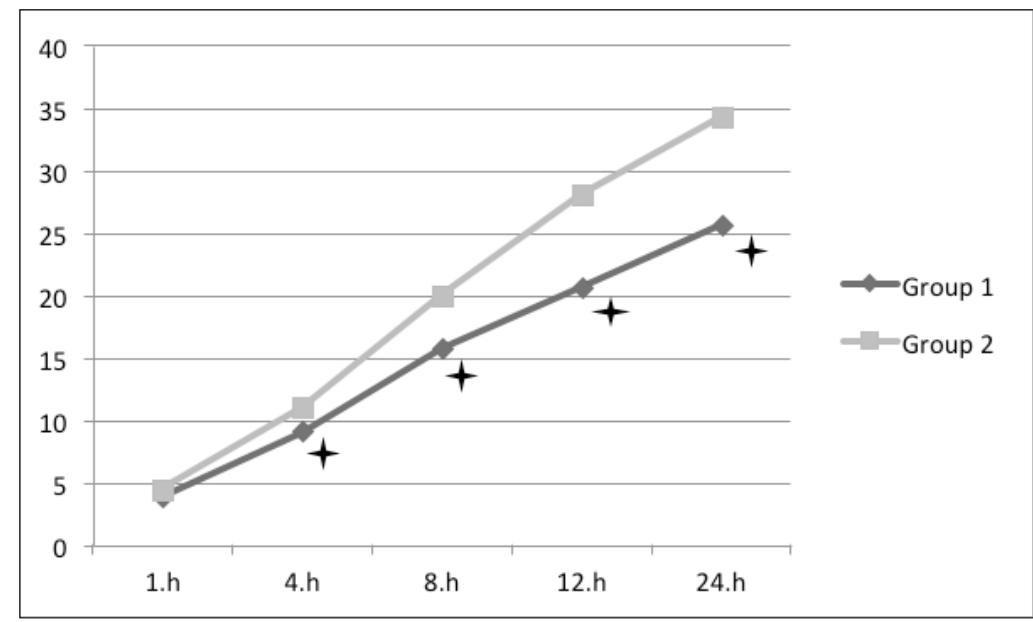

Figure 2. Morphine comsuption at $1 \mathrm{~h}, 4 \mathrm{~h}, 8 \mathrm{~h}, 12 \mathrm{~h}$ and $24 \mathrm{~h}$ of the groups. $\mathrm{Re}-$ sults are expressed as mean \pm SD. 
adequate dose to last throughout the surgical procedure. Thus, we assumed that the methodological error of the previous studies was corrected.

It is thought that NSAIDs prevent the sensitization of nociceptors by decreasing the synthesis of prostaglandins via the inhibition of the cyclooxygenase enzyme. Thus, they contribute to the prevention of central sensitization by decreasing afferent inputs. To evaluate the efficacy of non-steroidal anti-inflammatory drugs in preventive analgesia. When pre-incision NSAIDs drugs were compared with a placebo, the postoperative consumption of morphine and the VAS values were lower. ${ }^{[4,10]}$ It is not certain whether these results are attributable to the addition of a drug with known analgesic properties to the morphine medication or to its preventive action.

To evaluate the preventive efficacy of NSAIDS, studies investigating pre-incision and post-incision administration of these drugs were planned ${ }^{[11,12]}$ and they reported that NSAIDs can be effective to prevent postoperative pain. However, is this the preventive effect or, is this only inhibition of peripheral sensitization?

When side effects were evaluated in the present study, we observed that no adverse effects of ketamine, such as hallucinations and cognitive impairment. But preventive administration did not decrease the frequency of adverse effects, although it reduced the dose of morphine. However, in both groups, the side effects of opioids and NSAIDs were mild and could be controlled.

The results of the present study indicated that when central sensitization was prevented with ketamine, dexketoprofen administered before the incision led to a lower rate of morphine consumption and more effective postoperative analgesia than post-incision administration. In our opinion, this result can be attributed to the preventive effect of dexketoprofen. It can be concluded that the preventive analgesia protocol we utilized is safe and efficient enough to be used in clinical practice.

\section{Conflict-of-interest issues regarding the authorship or article: None declared.}

\section{Peer-rewiew: Externally peer-reviewed.}

\section{References}

1. Vadivelu N, Mitra S, Schermer E, Kodumudi V, Kaye AD, Urman RD. Preventive analgesia for postoperative pain control: a broader concept. Local Reg Anesth 2014;7:17-22.

2. Laskowski K, Stirling A, McKay WP, Lim HJ. A systematic review of intravenous ketamine for postoperative analgesia. Can J Anaesth 2011;58(10):911-23. CrossRef

3. Parikh B, Maliwad J, Shah VR. Preventive analgesia: Effect of small dose of ketamine on morphine requirement after renal surgery. J Anaesthesiol Clin Pharmacol 2011;27(4):485-8.

4. Barbanoj MJ, Antonijoan RM, Gich I. Clinical pharmacokinetics of dexketoprofen. Clin Pharmacokinet 2001;40(4):245-62. CrossRef

5. Woolf CJ. Central sensitization: implications for the diagnosis and treatment of pain. Pain 2011;152(3 Suppl):S2-15.

6. Dahl JB, Kehlet H. Preventive analgesia. Curr Opin Anaesthesiol 2011;24(3):331-8. CrossRef

7. Chaparro LE, Smith SA, Moore RA, Wiffen PJ, Gilron I. Pharmacotherapy for the prevention of chronic pain after surgery in adults. Cochrane Database Syst Rev 2013;7:CD00830. CrossRef

8. Dullenkopf A, Müller R, Dillmann F, Wiedemeier P, Hegi TR, Gautschi S. An intraoperative pre-incision single dose of intravenous ketamine does not have an effect on postoperative analgesic requirements under clinical conditions. Anaesth Intensive Care 2009;37(5):753-7.

9. Bilgen $S$, Köner $O$, Türe $H$, Menda F, Fiçicioğlu C, Aykaç B. Effect of three different doses of ketamine prior to general anaesthesia on postoperative pain following Caesarean delivery: a prospective randomized study. Minerva Anestesiol 2012;78(4):442-9.

10. Alexander R, El-Moalem HE, Gan TJ. Comparison of the morphine-sparing effects of diclofenac sodium and ketorolac tromethamine after major orthopedic surgery. J Clin Anesth 2002;14(3):187-92. CrossRef

11. Gabbott DA, Cohen AM, Mayor AH, Niemiro LA, Thomas TA. The influence of timing of ketorolac administration on postoperative analgesic requirements following total abdominal hysterectomy. Eur J Anaesthesiol 1997;14(6):610-5.

12. De Oliveira GS Jr, Agarwal D, Benzon HT. Perioperative single dose ketorolac to prevent postoperative pain: a meta-analysis of randomized trials. Anesth Analg 2012;114(2):424-33. CrossRef 